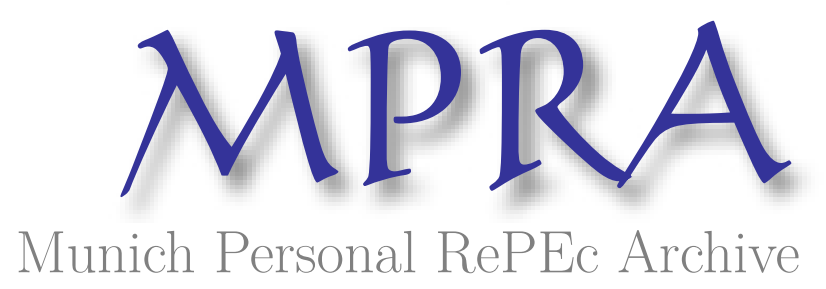

\title{
Administrative law aspects of the legal relations between The Regional Governor and The Council of Ministers
}

Dimitrova, Darina

2020

Online at https://mpra.ub.uni-muenchen.de/101043/

MPRA Paper No. 101043, posted 17 Jun 2020 10:13 UTC 
Научни трудове на Съюза на учените в България - Пловдив. Серия А.Обществени науки, изкуство и култура. Том VI, 2020. ISSN 1311-9400 (Print); ISSN 2534-9368 (Online), Scientific works of the Union of Scientists in Bulgaria Plovdiv. Series A. Public sciences, art and culture. Vol. VI, ISSN 1311-9400 (Print); ISSN 2534-9368 (Online), 2020.

\title{
ADMINISTRATIVE LAW ASPECTS OF THE LEGAL RELATIONS BETWEEN THE REGIONAL GOVERNOR AND THE COUNCIL OF MINISTERS \\ Darina Dimitrova \\ Varna University of Economics
}

\begin{abstract}
Summary: The paper examines the administrative law aspects of the legal relations between the regional governor and the Council of Ministers as the central body of the Executive. It clarifies the role of the regional governor as a local body of the Executive implementing the State's policy. On the basis of this analysis the author draws conclusions and makes generalizations of theoretical and practical value.
\end{abstract}

Keywords: Council of Ministers; Regional Governor; the Executive.

\section{Introduction}

The Constitution adopted in 1991 defined the status of the region as an administrativeterritorial unit for conducting regional policy, implementing the State's policy at the local level and reconciling national with local interests. The year 1991 also saw the adoption of the Local Government and Local Administration Act (LGLAA) whose Chapter Nine initially defined the regions' status and the powers of the regional governor. With the adoption of the Administration Act (AA) in 1998 Chapter Nine of LGLAA was repealed and the powers of the regional governor were laid down in $\mathrm{AA}^{1}$.

Since its adoption AA has undergone several dozen amendments, the last one in September 2018. The dynamics in the legislation with respect to the powers of the bodies of the Executive and the structure and organization of their administrations determines the relevance of the subject. Good interaction between local and central bodies is a prerequisite for government to the benefit of citizens. This implies not only political correctness, but also good knowledge of state government at doctrinal level, which will contribute to the appropriate exercise of the powers of the executive bodies. The regional governor (Dimitrova, 2008) is an intermediate between the Council of Ministers (CoM) and other central executive bodies on the one hand, and municipal bodies of the Executive (municipal mayors) and bodies of local self-governance (municipal councils) on the other hand.

The aim of this study is to examine the legal relations between the regional governor and the Council of Ministers in their administrative law aspects. This scholarly aim is achieved by pursuing the following objectives: 1) Analyse the specifics of the legal relations between the regional governor and the CoM; 2) Clarify the role of the regional governor in implementing the State's policy at the local level; 3) Draw conclusions and make generalizations on the matter of theoretical and practical value.

\footnotetext{
${ }^{1}$ Promulgated in State Gazette No. 130 of 5 November 1998, ... last amendment promulgated in Stage Gazette No. 80 of 28 September 2018.
} 
This study is a continuation of the author's research interest in the field of local governance ${ }^{2}$. The paper is consistent with the legislation existing in October 2019.

The administrative apparatus of the State is organized as a system of bodies and agencies that could be likened to a pyramid of units operating at different levels centrally and locally and featuring certain dependencies on one another (Dermendzhiev, Kostov, \& Hrusanov, 2010, pp. 117). Characteristic of the administrative apparatus is the subordination of bodies and units within it. This subordination manifests itself in the dependence of the acts of the lower bodies on the higher bodies and in the exercise of supervision by higher bodies on lower bodies. The central government sits on top of the pyramid of administrative (executive) bodies (Andreeva \& Yolova, 2016, pp. 37).

The Administration Act lays down principles of the organization and activities of executive bodies, taking a new view on matters of administration (Slavova, 2002, pp. 47). One of these principles as set out in Art. 2, Para. 1 AA is the principle of subordination and coordination (principle of hierarchy). With regard to executive bodies, hierarchy is understood as being accountable to and under the supervision of both the legislature and other executive bodies (Slavova, 2002, pp. 50). In terms of administrative law, hierarchy has special significance as a structural and functional principle as it explains the essence of the pyramidal structure of state government. Such hierarchy leads to relations of subordination, but it also implies coordination in the actions of the bodies of the Executive.

The Administration Act defines the Council of Ministers as the central body of executive power (Art. 19, Para. 2, Item 1 AA). The Constitution does not expressly define it as the supreme executive body, but this position stems from provisions stipulating that the CoM shall exercise overall guidance over the state administration (Art. 105, Para. 2 of the Constitution), i.e. over the system of central and local executive bodies. The CoM accomplishes this task by establishing other administrative bodies and exercising supervision over their functions - e.g. it appoints regional governors who are accountable to the central government and obligated to submit to the $\mathrm{CoM}$ an annual report on the activities of regional administrations.

The CoM as the central collective executive body with general competence coordinates the activities of other executive bodies with a view to implementing a unified state policy (Art. 2 of the Rules of Organization of the Council of Ministers and its Administration - ROCMA). A particular form of guidance by the state administration and of ensuring implementation of government decisions at the local level is the appointment of regional governors. The governance of the region is carried out by a regional governor, whose main task is to ensure the implementation of the State's policy (Art. 143 of the Constitution), i.e. to enforce the decisions of the CoM.

Firstly, the regional governor implements the State's policy within the region and ensures consistency between national and local interests by organizing the preparation and implementation of regional strategies and programs for regional development (cf. Art. 143, Para. 3 of the Constitution and Art. 31, Para. 1, Items 1 and 2 AA). More specifically, the regional governor organizes the development and submission of the draft regional development strategy and the regional spatial development plan for discussion and coordination at the provincial development council and for adoption at the regional development council (Art. 21, Items 1 and 2 of the Regional Development Act - RDA).

The regional development strategy sets the medium-term objectives and priorities for the development of the region and the strategic guidelines for preparing municipal development plans (Art. 12, Para. 1 RDA). The regional governor and regional administrations as representatives of the central government work towards the implementation of the State's policy at the regional level,

\footnotetext{
${ }^{2}$ Darina Dimitrova was awarded $\mathrm{PhD}$ in Administrative Law and Procedure by the Specialized Scientific Council at the Higher Attestation Committee in 2010. The subject of her PhD thesis was "The Regional Governor as a Body of the Executive".
} 
while seeking and implementing ways to improve governance and strengthen the potential of the local administration. Regional development strategies are consistent with the objectives and priorities of the National Strategy for Regional Development, i.e. the regional policy of the Republic of Bulgaria. Therefore, the adoption of regional strategies requires allocation of targeted subsidies from the state budget to cover the additional costs of regional administrations incurred in the performance of strategic regional development planning activities.

Secondly, the regional governor implements the State's policy on spatial planning in the region (Art. 4, Para. 1 of the Spatial Planning Act - SPA). Under Art. 2 SPA, the CoM is the body that sets the basic guidelines and principles of spatial planning policy and adopts decisions to finance the spatial planning of the territory. In order to implement this aspect of the State's policy, depending on the spatial objectives and tasks of regional and inter-municipal significance, the governor can appoint a regional expert board on spatial planning and organize its activities so as to enable it to perform the functions conferred upon it by SPA. For example, the regional governor ensures the maintenance of public records of the acts issued for the preparation and approval of spatial plans and their amendments, of building permits issued and of commissioned buildings (Art. 4, Para. 4 SPA).

Thirdly, the regional governor is responsible for the preservation and protection of state property in the region (Art. 31, Para. 1, Item 3 AA). As a rule, state property is managed by the central bodies of the Executive (cabinet ministers and heads of other departments) (Art. 14 of the State Property Act). This prerogative may be delegated to the regional governor. State property, whose management is not delegated under the prescribed procedure, is managed by the regional governor per its location (Art. 18, Para. 1 State Property Act), who may arrange a tender to lease out such property under a lease contract (Art.19 State Property Act).

Fourthly, the regional governor implements the state policy in the region by liaising with the regional offices of the central administration of the Executive and supervising the implementation of acts and actions of their heads (Art. 31, Para. 1, Item 6 AA). The regional governor coordinates and supervises the activities of the regional offices of ministries and other administrative bodies that perform administrative services in the region, regardless of their hierarchical subordination.

Fifthly, for the purposes of implementing the State's policy the regional governor organizes and manages the activities aimed at protecting the population, the cultural and material values and the environment in times of disaster (Art. 31, Para. 1, Item 9 AA). According to Art. 64, Para. 1 of the Disaster Protection Act (DPA), the governor organizes and manages disaster protection in the region, coordinates and supervises the disaster preparedness of the regional administration, the regional offices of ministries and departments and the natural and legal persons in the region. For this purpose, the regional governor issues an order to establish a regional staff for the implementation of the regional plan for disaster protection and for interaction with national and municipal staffs; coordinates and supervises the preparation and implementation of the regional program to reduce disaster risk and of the regional plan for disaster protection. In this connection, the regional governor is vested with specific powers in case of disaster in the region. He or she may declare a state of emergency in the region or part thereof. The regional governor also organizes, coordinates and supervises the process of disaster relief and recovery. He or she exercises these powers in close cooperation with the central government. When a state of emergency is announced for the entire region or a part thereof by way of an order, a copy of such order is immediately sent to the Minister of the Interior (Art. 50, Para. 2 DPA).

As evident from the foregoing, the regional governor has a number of powers conferred upon him or her by law or by a decree of the CoM. It takes very good organization and coordination of activities performed by central and local executive bodies to achieve the State's policy for effective national and local governance. In order to achieve this goal, the principles of decentralization (Dimitrova, 2003) and deconcentration (Dimitrova, 2006) need to be followed so as to strengthen the partnership between different levels of government. There is a need for vertical coordination from the CoM to regional governors, and also for horizontal coordination with governors of neighbouring regions. 
The legal relations between the regional governor and the central bodies of the Executive do not only consist in the implementation of decisions of the CoM at the regional level. These relations are also characterized by feedback from bottom to top, i.e. from the regional governor to the central government. This principle is envisaged in ROCMA. The Council of Ministers exercises the right of legislative initiative, but the regional governors have the right to submit their proposals for inclusion of draft bills in the legislative program of the central government via the respective Deputy Prime Minister or Minister (Art. 30, Para. 3 ROCMA). Regional governors are also entitled to submit draft acts prepared by them via the respective Deputy Prime Minister or Minister (Art. 31, Para. 3 ROCMA).

The legal relations between the regional governor and the central bodies of the Executive have another aspect, namely the issue of the supervision to be exercised by the central government over the activities of regional governors. In its Art. 103, Item 15 the Constitution of 1971 stipulated that the Council of Ministers had the power to revoke unlawful or inexpedient acts and actions of local executive bodies (executive committees of the people's councils). In contrast, the Constitution of 1991 does not vest such powers in the central government. This is explained by the decentralization of power enshrined in our new legislation (Stoychev, 1995, pp. 325). The central executive bodies can no longer revoke acts of local bodies. Although these local bodies carry out, among other tasks, the State's policy in their respective region, their relations with the central government are relatively autonomous and they enjoy certain independence in the exercise of their powers.

The general rule is that the supervision over the activity of certain bodies is exercised by the body that appointed them in the first place. Consequently, since regional governors are appointed by the Council of Ministers, the latter will have supervision over them. This idea is enshrined in the AA itself, whose Art. 57, Para. 3 and Art. 59 provide that the regional governor is accountable to the CoM, to which he or she shall submit an annual report on the activities of the regional administration $^{3}$. The regional governor shall also submit to the Secretary General of the CoM an annual report on the current state of the regional administration (Art. 6, Para. 2 of the Rules of Organization of the Regional Administrations - RORA). However, such supervision does not apply to acts of the regional governor. Within the framework of his/her powers, the regional governor issues orders that may be appealed before the competent administrative court.

The relations between the regional governor and the CoM are built on the principle of subordination, where the body with lower standing in the hierarchy is accountable to and has its activities supervised by the higher body in the hierarchy. The accountability of the governor to the $\mathrm{CoM}$ is mostly political. The supervision exercised by the central government is one over the implementation by the regional governor of state government at the local level and ensuring the consistency between national and local interests in the conduct of regional policy. The CoM may dismiss the regional governor without notice and at its discretion, as the most severe form of supervision over the governor's activities.

\section{Conclusion}

The Constitution of 1991 introduced a new executive body, which had no analogue in the past few decades - the regional governor. Given his/her functions, namely primarily to carry out the central government's policy in the region, we can define the work of the regional governor as deconcentration in governance, i.e. delegation of public powers by the central government to lower-standing bodies.

The main function of the regional governor is not to reconcile differences in the interests of the various municipalities (Dimitrova, 2005). Although the governor may and should do so, his/her primary function as a representative of the central government is to implement the State's policy in the region, ensure consistency between national and local interests, ensure security and

3 As ruled in Constitutional Court Decision No. 2 of 21.01.1999 in Constitutional Case No. 33/1998 (State Gazette No. 8/1999). 
public order in the region and exercise control over the legality of acts of local government bodies, where provided by law.

As stated above, our public administration has a pyramidal structure in terms of clear-cut lines of competence, governance, subordination, supervision and accountability. Relations between the central and local government arise out of or are being created on the grounds of legal provisions in the applicable legislation. These relations are governed mainly by the general laws: AA and LGLAA. This facilitates the creation of an effective system of partnership and mutual respect for the interests of the local and central government, but because of the diverse nature of the various relations it is difficult to build a unified system of rules governing each case.

The legal relations between local and central government raise the issue of the reconciliation of local self-governance with State control. On the one hand, if the central government in a unitary state did not supervise the work of local authorities, the latter would have the status of fully autonomous bodies. No sovereign country can tolerate such arrangement without being threatened to turn into a federation of independent communities. On the other hand, if the local selfgovernance bodies did not have the right to take independent decisions, they would be mere divisions of the central government at the local level. Therefore, the legal relations between central and local bodies require partnership and balance between supervision and independence of powers.

This partnership and balance is achieved through the institution of the regional governor. The latter is the intermediate between the central government (CoM), local self-governance bodies (municipal councils) and municipal bodies of the Executive (mayors). The regional governor coordinates and supervises the implementation of the acts and actions of the heads of territorial units of the central government in the region. The existence of regional level of governance creates favourable opportunities for balancing the national and local interests and reduces polarization in the organization of the administration.

\section{References}

1. Andreeva, A., \& Yolova, G. (2016). Osnovi na publichnoto pravo. Varna: Nauka i ikonomika.

2. Dermendzhiev, I., Kostov, D., \& Hrusanov, D. (2010). Administrativno pravo na Republika Bulgaria: Obshta chast. Sofia: Sibi.

3. Dimitrova, D. (2003). Detsentralizatsiyata na darzhavnata vlast - predpostavka za povishavane kachestvoto na zhivot v balgarskoto obshtestvo. Kachestvo na zhivot i harmonia v obshtestvoto (pp. 59-63). Varna: VSU "Chernorizets Hrabar".

4. Dimitrova, D. (2005). Pravni otnoshenia na oblastnia upravitel s organite na izpalnitelnata vlast i na mestnoto samoupravlenie. Izvestia na IU-Varna(4), 91-99.

5. Dimitrova, D. (2006). Pravni aspekti na dekontsentratsiyata na darzhavnoto upravlenie v oblastta. Godishnik na IU-Varna, tom 78, pp. 233-272.

6. Dimitrova, D. (2008). Praven statut na oblastnia upravitel. Godishnik na IUVarna, tom 80, pp. 285-318.

7. Slavova, M. (2002). Printsipi na administrativnoto pravo. Sofia: Sibi.

8. Stoychev, S. (1995). Konstitutsionno pravo na Republika Bulgaria. Albatros..

6. Dimitrova, D. (2008). Praven statut na oblastnia upravitel. Godishnik na IUVarna, tom 80, pp. 285-318.

7. Slavova, M. (2002). Printsipi na administrativnoto pravo. Sofia: Sibi.

8. Stoychev, S. (1995). Konstitutsionno pravo na Republika Bulgaria. Albatros.

Contact: Chief Assistant Darina Dimitrova, PhD, Varna University of Economics, darina@ue-varna.bg 